\title{
The Estimation of the Cointegration Relationship between Growth, Domestic Investment and Exports: The Indian Economy
}

\author{
Zafar Ahmad Sultan \\ Address: Assistant Professor, Dept. of Management, \\ College of Business Administration, Al Kharj \\ P.O. Box 165, Al Kharj, 11942. Kingdom of Saudi Arabia \\ Tel: 96-65-0917-8684Ｅ-mail: zsultan.sultan@gmail.com \\ Md Imdadul Haque (Corresponding Author) \\ Assistant Professor, Dept. of Management, College of Business Administration, Al Kharj \\ P.O. Box 165, Al Kharj, 11942. Kingdom of Saudi Arabia
}

Tel: 96-65-9672-1827 E-mail: mdimdadulhaque@gmail.com

Received: June 10, 2010

Accepted: July 5, 2010

doi:10.5539/ijef.v3n4p226

\begin{abstract}
The paper examines the relationship between domestic investment, export and economic growth in India during 1970-71 to 2007-08. Using Johnson's cointegration methodology the study found the presence of a long term relationship between investment, exports and the economic growth of India. The study further shows that only domestic investment significantly contributes to economic growth both in the long run and in the short run. The export, though, has positive relation with economic growth, its contribution has not been found to be significant. The policy implication is that India should continue to focus on domestic investment while diversifying investment towards promoting export sector through investments in infrastructure.
\end{abstract}

Keywords: Growth, Investment, Export, Cointegration, ECM

JEL: C32, E22, F10, F43.

\section{Introduction:}

The Indian economy has been experiencing a modest economic growth since the decade of seventies. The annual compound growth rate of the gross domestic product (GDP) for the period 1970-71 to 2007-08 was 5.58\%. Domestic investments played a key role in its growth process. The annual compound growth rate of domestic investment measured by gross domestic capital formation (GDCF) was $7.64 \%$ for the period 1970-71 to 2007-08. The economic growth of India has been for the most part facilitated by domestic savings and investments. GDCF as a percent of GDP more than doubled from $15 \%$ to around 38\% during the period. These investments in the form of GDCF have led to an increase in the country's production and output measured in terms of GDP (Singh, 2009). This goes well along with the implication of neo-classical growth models which emphasize the importance of savings and investments for economic growth. Basu (2008) has hailed this rise in savings and investment to be the most important macroeconomic development in India since 1970s, while Shome (2006) and Mohan (2008) advocate the need of enhancing investments for supporting higher growth rates. India has made a remarkable achievement as its domestic investment has grown from $15.05 \%$ of GDP in 1970-71 to $37.71 \%$ of GDP in 2007-08 but gaining further increase of the same magnitude and at the same rate will be easier said than done and in the neo classical framework the recent surge in investment rates may have a minimal effect on the country's growth rate in future (Robertson, 2010). There are also fears that continuously high investments may eventually be at the cost of current consumption and might lead to the funding of projects with low rates of return (Krugman, 1996). Investment is a necessary condition for sustaining economic growth but that's not sufficient and investment beyond a level makes investment led growth strategy unsustainable as it leads to excess productive capacity which further leads to deflation, financial instability and unemployment, thereby hampering growth as it happened in East Asian countries before the crisis in 1997 (Garnaut and Huang, 2005).

Another important determinant of growth is trade and the gains thereof as brought about by prominent models like absolute advantage and comparative advantage. The gains from trade are because of specialization, increased 
capacity utilization, reaping of the benefits of economies of scale and improved productivity. The annual compound growth rate of exports was $9.36 \%$ for the period 1970-71 to 2007-08 but Dashmishra (et.al, 2010) did not find a causal relation between export and GDP growth in India during the period 1970 to 2004. While Tendulkar (1999) has attributed the laggard performance of the export sector to the labor intensive nature of India's exports and Banik (2007) has blamed it on poor infrastructure and supply side bottlenecks. Though India did not have a vibrant export sector in the pre liberalization period, that is, before 1991, but Poddar (2004) affirmed a boom in exports since the reforms of 1991. The reforms of 1991 and subsequent measures dismantled the licensing system, reduced tariffs, phased out quantitative restrictions, made the exchange rate system market based and liberalized capital inflow. These reforms transformed the Indian economy from an inward looking economy promoting import substitution policies to an outward looking economy actively practicing export promotion policies. The growth rate of GDP for the pre-liberalization period (1970-71 to $1989-90$ ) was $4.46 \%$ which increased to $6.3 \%$ in the post reform period (1990-91 to 2007-08).

Export led growth strategy has been vigorously emphasized by Michaely (1977), Balassa (1978) and Darrat (1987) particularly for developing countries. This export led growth is also supported by the growth rates of South Korea, Taiwan, Hong Kong and Singapore since seventies and China presently. But recently after the East Asian Financial crisis of 1997 and the recent financial crisis there has been a marked change in this approach as is observed in the Trade and Development Review (TDR, 2010) which urges against using export led growth strategy alone as all countries cannot be net exporters at the same time and more importantly as the global demand in general and United States' demand in particular is destined to be low owing to the recent recession. Also for developing countries like India, emphasis on exports leads to compression of wages and it leads to unemployment. In such a situation domestic demand assumes further importance, whereby domestic investments in fixed capital formation leads to an increase in domestic demand as there is a corresponding rise in wages and employment.

These three macroeconomic variables are interrelated as investments lead to production resulting in growth and also when the produced output is exported it leads to growth. Moreover as the growth process of a developing country like India depends upon imported capital goods, it is a compulsion to have foreign exchange reserves which can be augmented by exports. Also, exports leads to investment, investment stimulates further investment and finally leads to growth (Jha, 2006). Past researches had ascertained cointegrating relationships between growth, investment and exports for Japan (Amano, 2005), Greece (Dritsakis et al., 2006), Romania (Marinas, 2007), Vietnam (Anh, 2008), korea and Taiwan (Yoo, 2008), Turkey (Akhtar et al., 2008), Nigeria (Chimobi, 2010), China (Herrerias and Ortis, 2010), and Malaysia (Tan and Lean, 2010). These studies have had used cointegration to study the impact of export and domestic investment on the GDP. In these countries, economic growth was stimulated both by investments and exports. Although for India, some researches (e.g., Sinha, 1999 and Kaushik et al., 2008) established a cointegrating relationship between economic growth, export instability and investment, but as per the review done by this study there have been no major studies to determine in the multivariable framework as to which strategy, whether export or investment, or both has led to growth in India. While analyzing the relationship between economic growth, domestic investment and exports, the paper aims to examine the relative contribution made by domestic investments and exports in the economic growth of India since 1970. The importance of this study stems from the fact that the dynamic linkages between these macroeconomic variables will have important policy implications.

\section{Model Specification and Methodology:}

Based on the methodology of the above reviewed studies this study aims to find the relationship between economic growth, domestic investment and exports. As is evident from the review of past studies on various countries there is a cointegrating relationship between economic growth, domestic investments and exports. The long run growth model this study aims to estimate is:

$\mathrm{GDP}_{\mathrm{t}}=\mathrm{f}\left(\mathrm{GDCF}_{\mathrm{t}}, \mathrm{X}_{\mathrm{t}}\right)$

Where, GDP $_{t}$ is real GDP obtained by deflating nominal GDP by wholesale price index in time period t.GDP is taken as a proxy for economic growth. $\mathrm{GDCF}_{t}$ is real gross domestic capital formation obtained by deflating nominal GDCF by wholesale price index in time period t. GDCF has been taken as a proxy for domestic investment. $\mathrm{X}_{\mathrm{t}}$ is real export measured as ratio of nominal export and wholesale price index in time period $\mathrm{t}$.

For estimation purpose, the choice between linear and log linear model is important because the functional forms affect the explanatory power of the variables. Kmenta (1986) argued that the misspecification of a functional form may result in misspecification of an error term, which in turn results in violation of assumption of the Ordinary Least Squares (OLS) method and hence affects efficiency and biasness of the parameter. There are different test for the selection of appropriate model, however Khan and Ross (1977), Boylan et al (1980), and Doroodian (1994) are of the view that the log linear model should be preferred over linear model because of certain advantages associated 
with it. It allows the researcher to interpret the coefficients of the dependent variables directly as elasticities with respect to the independent variables. Therefore, we have a constant value of elasticity for the entire set of data. It is also useful for accommodating the hetreoskedasticity problem (Goldstein and Khan, 1976).

$l \mathrm{GDP}_{\mathrm{t}}=\delta 0+\delta_{1} l \mathrm{GDCF}_{\mathrm{t}}+\delta_{2} l \mathrm{X}_{\mathrm{t}}+\varepsilon_{\mathrm{t}}$

Where $\varepsilon_{\mathrm{t}}$ is white noise error term and is normally distributed. $l$ indicates the natural logarithm of the respective variables.

Annual data has been used for the period 1970-71 to 2007-08. The data on these variables has been taken from the Handbook of Statistics published by Reserve Bank of India and the Economic Survey of India published by the Ministry of Finance, Government of India. Since the data used in the present study is time series in nature, the study begins the analysis by examining the time series properties of the data. If all the variables are stationary, we can apply OLS method to estimate the nature of relationship among the variables. If they are non stationary, application of OLS method may give spurious result (Granger and Newbold, 1974). In such cases, to examine the presence of long run relationship between the variables, the cointegration and ECM is considered to be the better method. When the variables are non stationary at level but are integrated of the same order, there can still be long run relationship between them if they are co-integrated. The variables are said to be co-integrated if a linear combination of these variables are stationary. When the variables are co-integrated it can be said that there exists a stable long run relationship between the variables. Once the cointegration among the variables is established, the ECM is estimated to examine the short run dynamics of the relationship.

In the present study, in order to test the order of integration, the Augmented Dicky-Fuller (ADF) test and Philips-Perron (PP) test is applied. To test the presence of cointegration, the Johansen (1988) approach has been applied. In this method, the number of cointegrating relations is tested on the basis of trace statistics and maximum Eigen statistics. Once presence of cointegration is established, we estimate an ECM that includes both long run and short run information.

$\Delta G D P_{t}=\alpha_{0}+\delta E C T_{t-1}+\sum_{i \in 1}^{n} \alpha_{1 i} \Delta G D P_{t-i}+\sum_{j=1}^{n} \alpha_{2 i} \Delta X_{t-i}+\sum_{i=1}^{n} \alpha_{3 i} \Delta G D C F_{t-i}+\varepsilon_{t}$

ECM consists of two types of components. Onde, error correction ${ }^{1}$ term with one period lag $\left(\mathrm{ECT}_{\mathrm{t}-1}\right)$. The coefficient of error correction term $(\delta)$ is the feedback effect or the adjustment effect. Two, the first difference lagged regressors, the coefficients of which $\left(\alpha_{2 i}, \alpha_{3 i}, \alpha_{4 i}\right)$ are impact multipliers (short run effects) that measure the immediate impact that a change in regressors will have on the dependent variable. And, $\varepsilon_{t}$ is a white noise error term.

\section{Empirical Analysis:}

3.1 Unit Roots and Cointegration (Long run dynamics): As the Johansen's cointegration requires the variables to be integrated of the same order, we apply ADF and PP tests to determine the order of integration of all the variables. The results of ADF and PP tests are given in Table 1a and 1b. The table shows that the test statistics of all the variables at level are less than the critical values. Hence the null hypothesis that all the variables are non stationary at level is accepted. The tables further show that the test statistics of all these variables at first difference are greater than the critical values, hence it is concluded that all these variables are integrated at order one. Also, the result of cointegration and ECM is significantly affected by the lag length of the variables. A maximum of three period lag is taken to find the appropriate lag length as the present study is using annual data and on the basis of Schwarz Information Criterion (SC) a one period lag is taken to estimate ECM (Table 2).

The results of cointegration analysis are given in Table $3 \mathrm{a}$ and $3 \mathrm{~b}$. The tables show that the trace statistics and maximum Eigen values are greater than the critical values at 5 percent and 10 percent level of significance respectively, for no cointegration $(\mathrm{r}=0)$ and less than the critical values for at least one cointegration $(\mathrm{r} \leq 1)$. Hence it is evident that there is one cointegrating vector among the three variables included in the model. In other words, there is a unique long run equilibrium relationship between GDP, GDCF and exports of India. The long run relationship can be expressed in the following form:

$$
\operatorname{lGDP}_{\mathrm{t}}=4.617315+0.7250581 \mathrm{GDCF}_{\mathrm{t}}+0.0227241 \mathrm{X}_{\mathrm{t}}
$$

$$
\text { (0.51648) (0.12190) }
$$

The figures in the parentheses indicate the standard error of the coefficients. The normalized cointegration equation shows that both the coefficients have positive sign, as expected. The significant relationship between domestic investment and GDP with a coefficient of 0.72 implies that a 10 percent increase in domestic investment leads to about 7.2 percent increase in GDP. Export, however, is not found to be significantly affecting GDP growth. This finding is also supported by Dashmishra (et.al, 2010) who did not find a significant contribution of exports in India's economic growth. A probable reason could be the considerably slower pace of trade liberalization. 
3.2 Estimation of Error Correction Model (Short Run Dynamics): The result of the ECM is given in Table no. 5. The model seems to be fit in the sense that it satisfies the diagnostic test. The result of the diagnostic tests shows that there is no serious problem of either serial correlation or heteroskedasticity. The error term is also found to be normally distributed. The coefficient of the error correction term with one period lag is negative and significant signifying that the above long run relationship is stable and unique and any disequilibrium created in the short run will be temporary and will get corrected over a period of time. The magnitude of the coefficient shows that GDP will adjust about 29 percent of its total deviation from the long run equilibrium level in one time period i.e. in a year. The result further shows that domestic investment has positive and significant relation with economic growth of the country in the short run as well. Although export has a positive influence on GDP but its contribution is not significant.

\section{Conclusion:}

Using time series data for the period 1970-2008 the study attempts to assess the relationship between economic growth, domestic investment and exports in India. The variables are first tested for stationarity using ADF and PP test. As all the variables are integrated at order one the Johansen's cointegration and ECM are applied to get the long term and short term relationships respectively. The trace statics and maximum Eigen value indicate one cointegrating vector, implying a long run relationship between the variables. All the variables under study, that is, gross domestic capital formation and exports are found to have a positive relation with economic growth. However, only GDCF has been found to be significantly related to GDP both in the short run and long run. The reason for insignificant relation of exports and GDP might be that this sector remained a tiny sector constituting less than 5 percent of GDP until 1991. It could reach double digit figures only by 2002.

India needs to keep up its momentum of growth in domestic investments. It would lead to an increase in overall production in the economy. With the recent downturn in the world economy, India also needs to concentrate on its already large and growing domestic demand. Increased investment would further increase the domestic demand via the multiplier effect. Investments, particularly in infrastructure would also lead to a reduction in the cost of export making our exports more price competitive in the world market.

Although in India's case exports have not been instrumental in increasing GDP but the positive sign of export coefficient signifies that stimulating export would definitely spur economic growth. What is required is accelerating the pace of trade liberalization and promoting the export sector. India can definitely improve upon this aspect to reap the benefits of trade. As the scope of increasing exports to developed countries is limited because of the recent economic slowdown and growing protectionism hence India needs to diversify its exports towards developing countries of Asia and Africa where in the recent past India has been able to increase its exports. This could also lead to diversification of its exports in terms of composition, as India can move from exports of traditional goods to technological and capital intensive goods.

Exports not only depend on external demand but also on internal production, that is, within the country production. Removing supply side bottlenecks would make domestic products cost effective and more competitive in the world market. The cointegrating relationship between growth, domestic investment and exports imply that there is a relationship between the three variables. Investments in infrastructure can facilitate production and increase exports. From the experiences of East Asian countries and China it is evident that tremendous economic growth can be achieved with high rate of growth of export volume. Further increase in investment together with diversification of investment towards export sector would lead to increase in the rate of economic growth of the country. Hence this study recommends improving upon the investment culture in the country and emphasizing upon infrastructural projects to facilitate exports.

\section{References}

Aktar, I., Ozturk, L., \& Demirci, N. (2008). The impact of FDI, export, economic growth, total fixed investment on unemployment in Turkey. Kirikkale University, Turkey. [Online] Available: http://ces.epoka.edu.al/icme/5.pdf.

Amano, M. (2005). Has economic growth been led by investment or export? Examination of Japanese, U.S., and U.K evidence. [Online] Available: http://www.le.chiba-u.ac.jp/../investment.pdf.

Anh, P. M. (2008). Can Vietnam's growth be explained by investment or export: A VAR analysis. VDF Working paper No: 0815. [Online] Available: http://www.vdf.org.vn/workingpapers/vdfwo0815.pdf

Balassa, B. (1978). Exports and economic growth: Further evidence. Journal of Development Economics, 5, 181-189. doi:10.1016/0304-3878(78)90006-8, http://dx.doi.org/10.1016/0304-3878(78)90006-8

Banik, N. (2007). India's exports: Is the bull run over? Asia-Pacific Trade and Investment Review, 3(2), 47-66. 
Basu, K. (2008). The enigma of India's arrival: A review of Arvind Virmani's propelling India from socialist stagnation to global power. Journal of Economic Literature, 46(2), 396- 406. doi:10.1257/jel.46.2.396, http://dx.doi.org/10.1257/jel.46.2.396

Boylan, T.A., Cuddy, M.P. \& O'Muircheartaigh. I. (1980). The functional form of the aggregate import demand equation: A comparison of three European economies. Journal of International Economics, 10, 561-566. doi:10.1016/0022-1996(80)90006-9, http://dx.doi.org/10.1016/0022-1996(80)90006-9

Chimobi, O.P. (2010). The estimation of long run relationship between economic growth, investment and export in Nigeria. International Journal of Business and Management 5(4), 215-222

Darrat, A.F. (1987). Are exports an engine of growth? Another look at the evidence. Applied Economics, 19, 277-283. doi:10.1080/00036848700000102, http://dx.doi.org/10.1080/00036848700000102

Dashmishra, M. Bargal,H., Ghune,N., Saxena,B., \& Yadav, S.K. (2010). An empirical analysis of pre and post liberalization period of export growth in India. , Hawaii, 27-28 September, 2010. [Online] Available: http://www.wbiconpro.com/215-Hitendra.pdf.

Doroodian, K., Koshal, R.K. \& Al-Muhanna, S. (1994). An examination of traditional aggregate import demand function for Saudi Arabia. Applied Economics 26, 909-915. doi:10.1080/00036849400000052, http://dx.doi.org/10.1080/00036849400000052

Dritsakis, N., Varelas, E., \& Adamopoulas, A. (2006). The main determinants of economic growth: An empirical investigation with Granger causality analysis for Greece, European Research Studies Journal, IX, 47-58

Garnaut, R. \& Huang, Y. (2005). The risk of investment led growth. In Ross Garnaut and Ligang Song (Eds), The China boom and its discontents, Canberra: Asia Pacific Press, (Chapter 2).

Goldestein, M. \& Khan, M.S. (1976). Large versus small price changes and the demand for imports. IMF Staff Working Paper 3, 200-225.

Granger, C.W.J. and Newbold, P. (1974). Economic forecasting: The atheist viewpoint. In G.A. Renton (Ed.), Modeling the Economy, (London: Heinemann)

Herrerias, M. J \& Ortis, V. (2010). The driving forces behind China's growth. [Online] Available: http://www.revecap.com/encuentros/trabajos/pdf/031.pdf

Jha, R. (2006). A model of exports and investment in an open developing economy. Economic and Political Weekly, 41(9), 820-825.

Johansen, S. (1995). Likelihood-based inference in cointegrated vector autoregressive models. (New York: Oxford University Press). doi:10.1093/0198774508.001.0001, http://dx.doi.org/10.1093/0198774508.001.0001

Kaushik, K. K., Arbenser, L. N., \& Klein. K. K. (2008). Export growth, export instability, investment and economic growth in India: A time series analysis. Journal of Developing Areas, 41(2), 155-170. doi:10.1353/jda.2008.0018, http://dx.doi.org/10.1353/jda.2008.0018

Khan, M.S. \& Ross, K.Z. (1977). The functional form of the aggregate import demand equation. Journal of International Economics $\quad 7, \quad 149-160 . \quad$ doi:10.1016/0022-1996(77)90028-9, http://dx.doi.org/0.1016/0022-1996(77)90028-9

Krugman, P. (1996). Pop Internationalism, Boston: MIT Press.

Kmenta, J. (1986). Elements of Econometrics. (2nd ed.). New York: Macmillan.

Marinas, Marius-Corneliu. (2007). The estimation of the cointegration relationship between the economic growth, investments and exports. The Romanian case. Theoretical and Applied Economics. 7(512), 11-16.

Michaely, M. (1977). Exports and growth: an empirical investigation. Journal of Economic Development, 4, 49-53. doi:10.1016/0304-3878(77)90006-2, http://dx.doi.org/10.1016/0304-3878(77)90006-2

Mohan, R. (2008). Growth record of the Indian economy, 1950-2008: A story of sustained savings and investment. Economic \& Political Weekly, 43(19), 61-71.

Poddar, T. (2004), Understanding India's export dynamism of the 1990s, European Trade Study Conference Nottingham, United Kingdom, September 9-11.

Robertson, J. (2010). Investment led growth in India: Fact or mythology. Economic and Political Weekly, 45(40), 120-124

Shome, P. (2006). At the threshold of 10 per cent economic growth? Economic and Political Weekly, 41(11), 
940-943.

Singh, T. (2009). Does domestic saving cause economic growth? A Time-series evidence from India. Journal of Policy Modeling, 32(2), 231-253. doi:10.1016/j.jpolmod.2009.08.008, http://dx.doi.org/10.1016/j.jpolmod.2009.08.008

Sinha, D. (1999). Export instability, investment and economic growth in Asian countries: A Time Series Analysis Center Discussion Paper No. 799, Economic Growth Center, Yale University.

Tan, B.W \& Lean, H.H. (2010). An analysis of dynamic linkages between domestic investment, exports and growth in Malaysia, European Journal of Social Sciences, 16(1), 150-159.

Tendulkar, S.D. (1999). Exports in India's growth process. ICRIER Working Paper No. 46. [Online] Available: http://www.icrier.org/pdf/Suresh\%20D.Tendulkar.pdf

UNCTAD (2010). Trade and Development Report, Employment, globalization and development, UN: New York and Geneva. [Online] Available: http://www.unctad.org/en/docs/tdr2010_en.pdf

Yu, Q (1998). Capital investment, international trade and economic growth in China: Evidence in the 1980-90s, China Economic Review, 9 (1), 73-84. doi:10.1016/S1043-951X(99)80005-4, http://dx.doi.org/10.1016/S1043-951X(99)80005-4

Yoo, Yoon-Ha. (2008). The East Asian miracle: export or investment led. KDI School of Public Policy and Management Working Paper Series. [Online] Available: http://www.kdischool.ac.kr/faculty/paper.asp

Table 1a. Results of Unit Root Tests (Augmented Dicky-Fuller Test)

\begin{tabular}{|c|c|c|c|c|c|c|c|}
\hline \multirow[t]{2}{*}{ Variables } & \multicolumn{3}{|l|}{ Level } & \multicolumn{3}{|c|}{ First Difference } & \multirow{2}{*}{$\begin{array}{l}\text { Order of } \\
\text { Integration }\end{array}$} \\
\hline & Constant & Constant and Trend & None & Constant & Constant and Trend & None & \\
\hline IGDP $_{\mathrm{t}}$ & 1.639329 & -2.980033 & 3.948726 & -4.522262 & -5.130960 & -2.086602 & $\mathrm{I}(1)$ \\
\hline IGDCF $_{\mathrm{t}}$ & 1.331472 & -1.807589 & 5.142613 & -6.254797 & -6.664127 & -1.895858 & $\mathrm{I}(1)$ \\
\hline$I X_{t}$ & 1.431212 & -1.229507 & 6.551651 & -5.271964 & -5.452909 & -10.60482 & $\mathrm{I}(1)$ \\
\hline $\begin{array}{l}\text { Critical Values } \\
\text { at } 1 \% \text { and } 5 \%\end{array}$ & $\begin{array}{l}-3.626784 \\
-2.945842\end{array}$ & $\begin{array}{l}-4.234972 \\
-3.540328\end{array}$ & $\begin{array}{l}-2.630762 \\
-1.950394\end{array}$ & $\begin{array}{l}-3.626784 \\
-2.945842\end{array}$ & $\begin{array}{l}-4.234972 \\
-3.540328\end{array}$ & $\begin{array}{l}-2.630762 \\
-1.950394\end{array}$ & \\
\hline
\end{tabular}

The critical values are those of McKinnon (1991). $\quad *$ and $* *$ represents significant at $1 \%$ and $5 \%$ respectively.

i.Lag lengths for the ADF test is chosen on the basis of the Schwarz Criteria (SIC).

Table 1b. Results of Unit Root Tests

(Philips-Perron Test)

\begin{tabular}{|c|c|c|c|c|c|c|c|}
\hline \multirow[t]{2}{*}{ Variables } & \multicolumn{3}{|l|}{ Level } & \multicolumn{3}{|c|}{ First Difference } & \multirow{2}{*}{$\begin{array}{l}\text { Order of } \\
\text { Integratio }\end{array}$} \\
\hline & Constant & Constant and Trend & None & Constant & Constant and Trend & None & \\
\hline IGDP $_{t}$ & 2.229806 & -3.251914 & 7.618849 & -4.487081 & -5.066339 & -1.872019 & $\mathrm{I}(1)$ \\
\hline IGDCF $_{t}$ & 1.932754 & -1.807589 & 5.352667 & -6.255107 & -6.769349 & -4.191263 & $\mathrm{I}(1)$ \\
\hline$I X_{t}$ & 1.379472 & -1.395747 & 5.949653 & -5.303577 & -5.454693 & -2.919188 & $\mathrm{I}(1)$ \\
\hline $\begin{array}{l}\text { Critical Values } \\
\text { at } 1 \% \text { and } 5 \%\end{array}$ & $\begin{array}{l}-3.621023 \\
-2.943427\end{array}$ & $\begin{array}{l}-4.226815 \\
-3.536601\end{array}$ & $\begin{array}{l}-2.628961 \\
-1.950117\end{array}$ & $\begin{array}{l}-3.621023 \\
-2.943427\end{array}$ & $\begin{array}{l}-4.226815 \\
-3.536601\end{array}$ & $\begin{array}{l}-2.628961 \\
-1.950117\end{array}$ & \\
\hline
\end{tabular}

The critical values are those of McKinnon (1991).

$*$ and $* *$ represents significant at $1 \%$ and $5 \%$ level.

i. .Number of truncation lags in the PP Unit root test determined by the Newey-West criterion.

Table 2. Lag Order Selection Criteria

\begin{tabular}{|l|l|l|l|l|l|l|}
\hline Lag & LogL & LR & FPE & AIC & SC & HQ \\
\hline $\mathbf{0}$ & 45.94932 & NA & $1.07 \mathrm{e}-06$ & -2.397104 & -2.219350 & -2.335743 \\
\hline $\mathbf{1}$ & 203.2914 & $269.7292 *$ & $3.35 \mathrm{e}-10^{*}$ & -10.47379 & $-9.585022^{*}$ & $-10.16699 *$ \\
\hline $\mathbf{2}$ & 218.6859 & 22.87186 & $3.61 \mathrm{e}-10$ & -10.43919 & -8.839407 & -9.886947 \\
\hline $\mathbf{3}$ & 237.3094 & 23.41236 & $3.44 \mathrm{e}-10$ & $-10.58911^{*}$ & -8.278303 & -9.791417 \\
\hline
\end{tabular}

* indicates lag order selected by the criterion

LR is sequential modified LR statistics,

FPE denotes Final prediction error, AIC refers to Akaike Information criterion

$\mathrm{SC}$ is Schwarz information criterion,

HQ denotes Hannan-Quinn information criterion 
Table 3a. Result of Johansen's Cointegration Test Unrestricted Cointegration Rank Test (Trace)

\begin{tabular}{|l|c|c|c|c|}
\hline Hypothesized No. of CE(s) & Eigen Value & Trace Statistics & 0.05 Critical Value & Prob.** \\
\hline None* & 0.461205 & 36.85355 & 35.19275 & 0.0328 \\
\hline At most 1 & 0.305027 & 15.82724 & 20.26184 & 0.1826 \\
\hline At Most 2 & 0.096632 & 3.455244 & 9.164546 & 0.4993 \\
\hline
\end{tabular}

Trace test indicates 1 co-integrating eqn(s) at the 0.05 level

*denotes rejection of the hypothesis at 0.05 the level

**MacKinnon-Haug-Michelis(1999) p-values

Table 3b. Unrestricted Cointegration Rank Test (Maximum Eigen value)

\begin{tabular}{|l|c|c|c|c|}
\hline Hypothesized No. of CE(s) & Eigen Value & Max-Eigen Statistic & 0.05 Critical Value & Prob.** \\
\hline None*** & 0.461205 & 21.02631 & 22.29962 & 0.0745 \\
\hline At most 1 & 0.305027 & 12.37200 & 15.89210 & 0.1654 \\
\hline At Most 2 & 0.096632 & 3.455244 & 9.164546 & 0.4993 \\
\hline
\end{tabular}

Max-eigen test indicates 1 co-integrating eqn(s) at the 0.05 level

***denotes rejection of the hypothesis at 0.10 the level

**MacKinnon-Haug-Michelis(1999) p-values

Table 4. Estimate of Long Run Co-integrating Vector Normalized Coefficients

\begin{tabular}{|l|l|l|l|}
\hline$l \mathrm{GDP}_{\mathrm{t}}$ & $l \mathrm{RGDCF}_{\mathrm{t}}$ & $l \mathrm{RX}_{\mathrm{t}}$ & $\mathrm{C}$ \\
\hline 1.000000 & -0.725058 & -0.022724 & -4.617315 \\
& $(0.12190)$ & $(0.09304)$ & $(0.51648)$ \\
\hline
\end{tabular}

The figures in small parentheses indicate standard error of the coefficients.

Table 5. Result of Error Correction Model

\begin{tabular}{|c|c|c|c|}
\hline Variables & Coefficients & Standard Error & t-values \\
\hline $\mathrm{EC}_{\mathrm{t}-1}$ & $-0.291553^{*}$ & 0.08427 & -3.45979 \\
\hline D(LRGDP(-1)) & 0.055628 & 0.15493 & 0.35906 \\
\hline D(LRGDCF(-1)) & 0.116206 & 0.07147 & 1.62584 \\
\hline $\mathrm{D}(\operatorname{LRX}(-1))$ & 0.069159 & 0.06676 & 1.03599 \\
\hline $\begin{array}{l}\mathrm{LM}(1)=(0.9633) \\
\text { Hetroskedasticity } \\
\mathrm{JB} \text { test }=(0.1725)\end{array}$ & & & \\
\hline
\end{tabular}

* indicates significant at $5 \%$.

Figures in brackets show significance level. 